\title{
Translation, Transcultural Adaptation, Validation of the Holistic Critical Thinking Scoring Rubric to Brazilian Portuguese
}

\author{
Fernando Riegel ${ }^{1}$, Maria da Graça Oliveira Crossetti
}

\begin{abstract}
Objective: translation, transcultural adaptation, and validation of the Holistic Critical Thinking Scoring Rubric, original from the United States, to Brazilian Portuguese. Method: methodological study comprising the following steps: translation by 3 independent translators, transcultural adaptation by a Committee of 6 Nurses Experts; and validation, with the participation, in the pre-test, of 30 academics and 3 teachers-evaluators of Nursing field. The validity and reliability of the tool were verified by Kappa test. Results: the Portuguese version of the tool obtained a Kappa test score of 0.82 in the pre-test group. There was strong significant agreement among the evaluators. Conclusion: The Brazilian version of the Holistic Critical Thinking Scoring Rubric is a valid and reliable tool to evaluate the holistic critical thinking of Nursing academics at different levels of training, especially using active teaching methodologies.
\end{abstract}

Keywords: Critical thinking. Evaluation. Evaluation studies. Education. Teaching. Nursing.

\section{RESUMO}

Objetivo: traduzir, adaptar transculturalmente e validar o Holistic Critical Thinking Scoring Rubric, originado nos Estados Unidos, para o idioma português do Brasil. Método: estudo metodológico, que compreendeu as seguintes etapas: tradução realizada por 3 tradutores independentes, adaptação transcultural realizada por um Comitê de 6 Enfermeiros Experts; e validação, com a participação, no pré-teste, de 30 acadêmicos e de 3 professores avaliadores da área de Enfermagem. Verificou-se a validade e a confiabilidade do instrumento por meio do teste de Kappa. Resultados: a versão do instrumento em português obteve concordância no teste Kappa de 0,82 no grupo pré-teste. Houve concordância significativa forte entre os avaliadores. Conclusão: a versão brasileira do Holistic Critical Thinking Scoring Rubric é um instrumento válido e confiável para avaliar o pensamento crítico holístico de acadêmicos de Enfermagem em diferentes níveis de formação, especialmente por meio do uso de metodologias de ensino ativas.

Palavras-chave: Pensamento crítico. Avaliação. Estudos de validação. Educação. Ensino. Enfermagem.

\footnotetext{
Enfermeiro. Doutorado em Enfermagem (UFRGS). Mestrado em Educação (Unisinos). Professor do curso de Enfermagem da Universidade Federal de Mato Grosso (UFMT) - Campus Universitário do Araguaia, Barra do Garças, Mato Grosso, Brasil. fernandoriegel85@gmail.com

2 Professora titular da DEMC da Escola de Enfermagem da UFRGS. Livre docente em Enfermagem Fundamental - Universidade Estadual do Rio de Janeiro - RJ - Brasil. Doutorado em Filosofia na Enfermagem - Universidade Federal de Santa Catarina - SC - Brasil. Docente do Programa de Pós-Graduação EEUFRGS e do curso de Graduação em Enfermagem EEUFRGS. Líder do grupo de Pesquisa: Núcleo de Estudos do Cuidado em Enfermagem (Nece - EEUFRGS) com diretório no CNPq. mcrossetti@gmail.com
} 


\section{INTRODUCTION}

In nurses training process, the social transformations and economic practices verified during the last decades have caused changes in health care in a globalized society. These transformations are originated by a larger demand of individuals and a complexity increase of their problems; which demands professional accurate diagnoses, results, and interventions to promote care.

Nursing, as a health discipline, try to respond these and other challenges, developing its own knowledge. The aim is to train qualified nurses to provide adequate solutions to individuals' needs.

Nurses must have greater responsibility and autonomy in judgment and decisions, determining characteristics of a competent professional practice, as well as knowledge, experience and critical thinking. They must be added to characteristics such as creativity, empathy, compassion, and emotional and relational skills. However, this will only be possible through holistic critical thinking (HCT), thinking the whole unified and with quality in the process of making a judgment or opinion centered on deciding what to believe or what to do. For this, the critical thinker should not be negative or arrogant, but thoughtful or reflective and balanced, requiring people to express some kind of reason or basis for what they are saying (FACIONE; GITTENS, 2016).

HCT becomes a source of interest for teaching when analyzing the current situation of the world health scenario. The social and economic determinants demand speed and resolution capacity to the innumerable and distinct individuals' problems. It is important to apply the HCT to diagnose, intervene and determinate care outcomes responding to individuals' health needs. In this historical moment, when the focus of health systems is on the production of large-scale services to the detriment of the human aspects of care, such response is crucial.

To think critically helps a better performance in clinical practice. However, only $35 \%$ of newly graduated nurses are prepared to meet employers' expectations for critical thinking skills (PAUL, 2014). To educate nurses to think their function in a critical and holistic way is also to be attentive to a need imposed by the current society.

Academics and nursing professionals need to develop skills for critical thinking application, to acquire knowledge, skills and attitudes to think holistically, to achieve the best results in nursing and to advance in the nursing diagnostic, planning and patients' evaluation steps (LIMA; CROSSETTI, 2016).

HCT involves the cognitive abilities group, supported by certain mind habits, to arrive at a judicious and purposeful judgment. Good holistic critical thinkers apply analysis, interpretation, assessment, inference, explanation, and reflection skills to monitor and, if necessary, make corrections to their thinking. When they think, they do not waste their time thinking about part or fragment, but think with focus on wholeness (FACIONE; GITTENS, 2016).

The training of nursing professionals needs to be reoriented, with an emphasis on care approaches focused on the patients' needs in multiple dimensions. The nurses need to think in order to make clinical decisions beyond the evidence (BITTENCOURT; CROSSETTI, 2013). For this reason, the professional should think critically about the patient's health problems, in a logical and holistic way, which is expressed by holistic critical thinking.

In this way, one must teach nursing care with a focus on the totality of the being, to take care of the human being in a broad way, promoting dialogue, providing listening, interest and reception. This holistic care approach ensures interventions are developed for the individual and not just for the disease.

It is important to evaluate the holistic critical thinking of nursing students to develop it. The Holistic Critical Thinking Scoring Rubric (HCTSR) tool is original from the USA and stands out when used for this purpose.

HCTSR is an evaluation measure available in English, Spanish, Italian, Chinese, Russian, Latvian and Farsi versions. The transcultural translation and adaptation for use in Portuguese speaking countries is necessary. The HCTSR is used to evaluate holistic critical thinking through elements listed in 4 scores. HCT can be observed and demonstrated in presentations, reports, essays, projects, classroom discussions, classroom presentations, and other activities that require critical thinking (FACIONE, 1990; FACIONE; FACIONE, 2009).

HCTSR is a qualitative tool for assessing the holistic critical thinking quality. The validity and reliability of HCTSR classifications are due to the assessor ability to recognize and discriminate the thinking and reasoning processes variations. It is an evaluation rubric and can be defined as a scoring guide with specific criteria used to map the learner's performance. About rubrics, the holistic and 
the analytical rubrics can be mentioned. The holistic rubrics concentrate the assessment on the overall of the student's work. Analytical rubrics are used to map skills and all important components in complex evaluations, and can be performed in pairs, such as self-assessment and evaluation. As in all rubrics, it is necessary to teach and train evaluators to use this tool to establish valid and reliable classifications (FACIONE, 1990; FACIONE; FACIONE 2009).

HCTSR is a holistic assessment tool. It considers, in the evaluation process, a group of cognitive and behavioral abilities, supported by mind habits conferring quality to the thinking. The critical thinking scores in HCTSR are: (4) Strong, (3) Acceptable, (2) Unacceptable, and (1) Weak (FACIONE, 1990; FACIONE; FACIO$\mathrm{NE}$, 2009). The definition of HCTSR scores is presented as follows:

(1) Weak: Consistently performs all or almost all of the following: Provides biased interpretations of evidence, statements, graphs, questions, information, or points of view from others. Does not identify or reject strong and relevant counterarguments readily. Ignores or superficially evaluates the obvious alternative points of view. Argues using wrong or irrelevant motives, and unwarranted motives. Does not justify results or procedures and does not explain the reasons. Maintains or defends views, regardless of evidences or motives, based on self-interest or prejudice. Demonstrates closed mind or refuses to think logically.

(2) Unacceptable: Performs most or many of the following: Misrepresentation of evidence, statements, graphs, questions, etc. Does not identify strong and relevant counterarguments. Ignores or superficially evaluates the obvious alternative points of view. Makes unjustified or misleading conclusions. Justify few results or procedures, rarely explains the reasons. Maintains or defends, independently of the evidence or motives, points of view based on self-interest or prejudices;

(3) Acceptable: Performs most or many of the following: Accurately interprets evidence, statements, graphs, questions, etc. Identifies the most relevant arguments (reasons and justifications). Pros and cons. Proposes analyzes and evaluations of obvious alternative points of view. Makes justifiable, judicious, and true conclusions. Justify some results or procedures, explain the reasons. Follows, impartially, the path of evidence and motives;

(4) Strong: Consistently performs all or almost all of the following: Accurately interprets evidence, statements, graphs, questions, etc. Identifies the most relevant arguments (reasons and justifications). Pros and cons. Analyzes and carefully evaluates the main alternative points of view. Makes justifiable, judicious and true conclusions. Justifies the main results and procedures, explains hypotheses and reasons. Follows the path of evidence and motives impartially.

Teachers have found in HCTSR the ideal way to learn to think critically in various educational contexts. The use of HCTSR facilitates the understanding of the language of critical thinking in daily and practical conversation. It assists the teacher in the evaluation of the students critical thinking level in the classroom through the teaching results (FACIONE, 1990; FACIONE; FACIONE, 2009).

This study aimed to translate, transculturally adapt, and validate the Holistic Critical Thinking Scoring Rubric tool for Portuguese language in Brazilian context. A valid and reliable tool can be used in nursing education in different training contexts to carry out interventions aiding the evaluation and development of the HCT of nursing students. The instrument was validated with a local sample of 30 nursing students, however it needs future studies for the application of the instrument with different populations.

\section{METHODS}

It is a methodological study of translation, transcultural adaptation, and validation of the Holistic Critical Thinking Scoring Rubric Tool performed from December to May 2018. In this study, the following steps were taken for the translation and adaptation process: 1) translation process; (2) synthesis; (3) back translation; (4) evaluation by the Experts Committee; (5) semantic equivalence; and (6) validation (BEATON et al., 2007; ALEXANDRE; COLUCI, 2011).

As a prerequisite, in order to begin the process of translation and transcultural adaptation, prior contact with the author of the tool PhD Peter Facione, via electronic mail was made; the intentions regarding the research were presented to him. With the author's authorization, it was time for approval of the Ethics in Research Committee.

The study was carried out at a private higher education institution in Brazil. The institution consented the study. All participants of the research signed the Term of Free and Informed Consent in two copies, one for the participant and another one for the researcher.

Three independent translators, identified in the study as translator 1 (T1), translator 2 (T2) and translator 3 (T3) have participated in the study in the steps of trans- 
lation, synthesis and back-translation. Only (T1) knew the objectives of the study. The three translators mastered the tool's original language (English), and Portuguese is their mother tongue. They were from education field.

For the evaluation of the Committee of Experts, 6 experts in nursing field were invited. They are all nurses, nursing teachers with expertise in the field of research and had a minimum of 2 years working as a nurse. They also have 2 years of experience in applying the Nursing Diagnosis Process in teaching or care.

For the validation and completion of the Pre-test, 30 academic students of the Nursing Course, from 7th to 9th semester of Nursing graduation, were selected with support of the Nursing Course Coordinator of the higher education institution. In addition to 3 evaluating-teachers, including the researcher and others indicated by the institution course coordination for students HCT evaluation using HCTSR.

The translation of the HCTSR was made by T1 and T2. After the synthesis of the two translations, the back-translation was made by T3. The back translation was approved by the author and forwarded for evaluation by the Committee of Experts (teachers-nurses) and semantic equivalence. In this step, an acceptable Global Concordance Index (ICG) rate equal or larger than $79 \%$ agreement was considered by the Experts Committee, in order to validate the tool (NÓBREGA; GUTTIERREZ, 2000). After the analysis of the concordances by the evaluators of the Experts Committee, only 13 items presented agreement less than $79 \%$ and were forwarded for reassessment. 35 items of the tool were approved with $100 \%$ agreement in the semantic equivalence (BEATON et al., 2007; ALEXANDRE; COLUCI, 2011).

The validation of the tool was performed with 30 nursing students evaluated by 3 different teachers-evaluators. It was the pre-test. At this stage, a clinical case was applied, accompanied by a data collection form with three columns. The first column included the investigation (data collection); the second column, the nursing diagnoses; the third column, a space to justify the choice. In addition, participants were asked to fill out an attached checklist with the cognitive and behavioral skills, and HCT's mind habits, mobilized when they thought holistically to resolve the clinical case. For Nursing Diagnoses Process (NDP) application, academics were able to use the North American Nursing Diagnosis Association (Nanda-I) book material. The activity had two hours and thirty minutes.

The pre-test was performed with 30 nursing students through the application of a previously validated case study authored by Lunney that addresses a clinical patient diagnosed with cancer in palliative care. The theme addressed in the case was compatible with the contents studied by the research participants. The response template was prepared by the researcher and for validation of the template, a pilot test was performed with three case study evaluations, which did not make up the final pretest sample.

The clinical case was selected by prior assessment of the qualitative criteria of the instrument in the validation process that required the nursing student to apply holistic critical thinking in the elaboration of the nursing diagnosis process with the aid of the International Classification of Nursing Diagnoses (Nanda).

The teachers were trained by the researcher with a lecture-dialogued lecture of approximately 1 hour with practical application of the instrument and clarification of doubts by the researcher. Subsequently, copies of all clinical cases answered by the 30 academics were made available to all evaluators who applied the instrument and classified according to the evaluation score. The results of the evaluations were tabulated and statistically analyzed by applying the Kappa coefficient of agreement.

The data collected were analyzed through descriptive and inferential statistics. Data with normal distribution were presented in mean and standard deviation; and those with asymmetry, in median and interquartile range. Categorical variables were expressed in absolute and relative frequency.

In the comparison of proportions, Pearson's chi-square or Fisher's exact tests were applied. To evaluate the agreement between the evaluators, the kappa coefficient was applied. For this study, kappa values lower than 0.4 indicate poor agreement; between 0.41 and 0.60 , moderate agreement; and above 0.6, strong agreement. The SPSS version 21.0 program was used. In all cases, differences were considered significant when $\mathrm{p}<0.05$.

\section{RESULTS}

The pre-test was performed with thirty nursing students. The sociodemographic variables were associated with the respective scores obtained in the evaluation of the HCT of the students to characterize the participants according to the HCTSR score obtained. The prevalence of HCTSR $=2$ and 3 , obtained by 20 (66.6\%) of the participants (10 in each score), followed by the score $=1$, by $6(20 \%)$ was verified in the pre-test of the participants; and score $=4$, by $4(13.3 \%) \%$ of participants, according to Table 1, presented below: 
Table 1 - Association of the characterization variables of the sample with the HCTSR score in the pre-test. Porto Alegre, Rio Grande do Sul, Brazil, 2018

\begin{tabular}{|c|c|c|c|c|c|}
\hline Variables & Score HCTS & & & & \\
\hline & $\begin{array}{l}\text { Significantly weak } \\
(n=6)^{\ddagger}\end{array}$ & $\begin{array}{l}\text { Unacceptable } \\
(n=10)^{ \pm}\end{array}$ & $\begin{array}{l}\text { Unacceptable } \\
(n=10)^{\ddagger}\end{array}$ & $\begin{array}{l}\text { Strong } \\
(n=4)^{\ddagger}\end{array}$ & $p^{\S}$ \\
\hline Age (years) - average $\pm S D^{+}$ & $29.3 \pm 6.7$ & $35.5 \pm 11.5$ & $30.0 \pm 5.9$ & $31.8 \pm 6.2$ & 0.425 \\
\hline $\operatorname{Sex}-n(\%)^{\ddagger}$ & & & & & 0.033 \\
\hline Male & $0(0.0)$ & $5(50.0) *$ & $1(10.0)$ & $0(0.0)$ & \\
\hline Female & $6(100)$ & $5(50.0)$ & $9(90.0)$ & $4(100)$ & \\
\hline Marital status $-n(\%)^{\ddagger}$ & & & & & 0.965 \\
\hline Married & $3(50.0)$ & $4(40.0)$ & $4(40.0)$ & $2(50.0)$ & \\
\hline Not Married & $3(50.0)$ & $6(60.0)$ & $6(60.0)$ & $2(50.0)$ & \\
\hline Semester $-n(\%)^{\ddagger}$ & & & & & 0.771 \\
\hline 70 & $1(16.7)$ & $5(50.0)$ & $5(50.0)$ & $1(25.0)$ & \\
\hline 80 & $4(66.7)$ & $3(30.0)$ & $3(30.0)$ & $2(50.0)$ & \\
\hline 9은 & $1(16.7)$ & $2(20.0)$ & $2(20.0)$ & $1(25.0)$ & \\
\hline Works in the health field $-n(\%)^{\ddagger}$ & $3(50.0)$ & $6(60.0)$ & $9(90.0)$ & $1(25.0)$ & 0.107 \\
\hline \multicolumn{6}{|l|}{ Role in health field $-n(\%)^{\ddagger}$} \\
\hline Nursing technician & $2(66.7)$ & $2(33.3)$ & $8(88.9)$ & $1(100)$ & \\
\hline Intern & $1(33.3)$ & $1(16.7)$ & $1(11.1)$ & $0(0.0)$ & \\
\hline Other & $0(0.0)$ & $3(50.0)$ & $0(0.0)$ & $0(0.0)$ & \\
\hline $\begin{array}{l}\text { Experience in the health field } \\
\text { (years) - median (P25-P75) }\end{array}$ & $5(3-11)$ & $11(1.8-15.8)$ & $6(4-12)$ & $14(14-14)$ & 0.632 \\
\hline Course NP\| $-n(\%)$ & $0(0.0)$ & $0(0.0)$ & $1(10.0)$ & $2(50.0) *$ & 0.031 \\
\hline Define NP\| $-n(\%)$ & $6(100)$ & $10(100)$ & $9(90.0)$ & $4(100)$ & 0.558 \\
\hline Define $C T^{n}-n(\%)$ & $6(100)$ & $10(100)$ & $9(90.0)$ & $4(100)$ & 0.558 \\
\hline Course $C T^{n}-n(\%)$ & $0(0.0)$ & $0(0.0)$ & $1(10.0)$ & $0(0.0)$ & 0.558 \\
\hline
\end{tabular}

Regarding health field work, $19(63 \%)$ work in the field, with emphasis on the role of Nursing Technician, with 13 (43\%) \% participants. The total experience was between 5 and 15 years.

When evaluating the participation in Nursing Process extension courses, only $3(10 \%)$ participated in at least one extension course during University studies. About the knowledge of what Nursing Process means, 29 (97\%) knew what it was; 1 participant (3\%), however, did not know what to say.

In relation to the semester in which they started the contact with the approach of the Nursing Process, the highlight is the 3 rd semester, with 12 (40\%) notes. Regarding the importance of the nursing diagnosis process (NPD) in clinical practice, $30(100 \%)$ consider it important. When asked about knowledge in critical thinking, 29 (97\%) knew how to define critical thinking; but $1(3 \%)$ did not know what it was.

One highlight is the significant (p) of two participants $(p=0.031)$ with a strong HCTSR score. They participated in a Nursing Process field extension course. This fact points out the contribution of extension courses in nursing process to the performance of academics with high HCTSR scores.
Table 2 presents the critical thinking evaluations of the material produced by the pre-test group performed by 3 evaluating teachers, using the HCTSR tool. The concordance among the evaluators was analyzed with the Kappa coefficient, which showed a concordance above 0.6 , significantly strong, giving validity and reliability to the translated tool. This process validated the tool for application in Brazilian population.

Table 2 - Agreement among the evaluators in the Pre-test. Porto Alegre, Rio Grande do Sul, Brazil, 2018

\begin{tabular}{cccc}
\hline Score HCTSR & $\begin{array}{c}\text { Evaluator } 1 \\
\mathbf{n}(\%)^{\ddagger}\end{array}$ & $\begin{array}{c}\text { Evaluator } \mathbf{2} \\
\mathbf{n}(\%)^{\ddagger}\end{array}$ & $\begin{array}{c}\text { Evaluator } \mathbf{3} \\
\mathbf{n}(\%)^{\ddagger}\end{array}$ \\
\hline Significantly weak & $12(40.0)$ & $12(40.0)$ & $13(43.3)$ \\
Unacceptable & $10(33.3)$ & $8(26.7)$ & $9(30.0)$ \\
Acceptable & $7(23.3)$ & $9(30.0)$ & $7(23.3)$ \\
Strong & $1(3.3)$ & $1(3.3)$ & $1(3.3)$ \\
Kappa & $1 \times 2$ & $1 \times 3$ & $2 \times 3$ \\
Value-p ${ }^{\S}$ & 0.85 & 0.70 & 0.66 \\
$\neq n-$ Absolute Number; §P - Level of Significance. \\
\multicolumn{4}{c}{ Source: CROSSETTI; RIEGEL, 2018. }
\end{tabular}


In the pretest phase, the aim was also to evidence the association between HCTSR scores and the cognitive, behavioral, and habits skills of the mind mobilized at the time of PDE application in the applied clinical case study.

Participants with HCTSR $=4$ or strong score have considered as important cognitive abilities for the application of HCT in NDP: analysis, prediction, logical reaso- ning, interpretation and information search. About the behavioral skills, these participants have considered self-confidence and observation. And as for mental habits, understanding, contextual perspective, intuition, flexibility, perseverance, and impulsiveness management.

Of the six participants with score 1 or significantly weak, three (50\%) have cited analysis and knowledge as important cognitive abilities of HCT in

Figure 1 - Holistic Critical Thinking Scoring Rubric (HCTSR) translated into Brazilian Portuguese

\section{INSÏGHT} ASSESSMENT

\section{Raciocínio e Tomada de Decisão Mais Fortes \\ Ferramentas e Técnicas de Treinamento}

\section{Instrumento para Avaliação do Pensamento Crítico Holístico - HCTSR}

Uma Ferramenta para Desenvolvimento e Avaliação do Pensamento Critico

$$
\text { Peter A. Facione, Ph.D. and Noreen C. Facione, Ph.D. }
$$

Traduçalo: Femando Riegel, Ph D student and Meria da Graça Olimera Crossetti. Ph D.

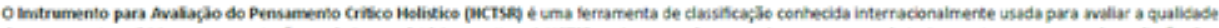

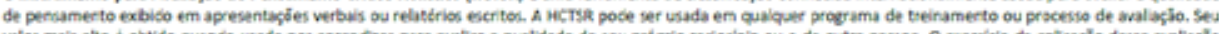

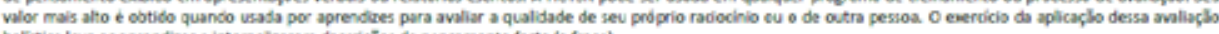

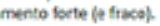

Forte 4: Executa consistentemente todos ou quase todos os seguintes itens:

Interpreta com precisăo evidencias, declaraç̋̄es, graficos, perguntas, etc. Identifica os argumentos mais relevantes (motivos e justificativas). Pró e contra. Analisa e avalia atentamente os principais pontos de vista alternativos. Elabora conclusōes justificadas, criteriosas e verdadeiras.

Justifica os principais resultados e procedimentos, explica hipóteses e motivos. Segue, com imparcialidade, o caminho das evidencias e motivos.

Aceitável 3: Executa a maioria ou muitos dos seguintes itens:

Interpreta com precisăo evidéncias, declaraçð̄es, gráficos, perguntas, etc. Identifica os argumentos mais relevantes (motivos e justificativas). Pró e contra. Propōe análises e avaliaçōes de pontos de vista alternativos óbvios. Elabora conclusôes justificadas, criteriosas e verdadeiras.

Justifica alguns resultados ou procedimentos, explica os motivos.

Segue, com imparcialidade, o caminho das evidencias e motivos.

Inaceitável 2: Executa a maioria ou muitos dos seguintes itens:

Interpreta equivocadamente evidências, declaraçōes, gráficos, perguntas, etc. Năo identifica contra-argumentos fortes e relevantes.

Ignora ou avalia superficialmente os pontos de vista alternativos óbvios. Elabora conclusరిes nåo justificadas ou equivocadas.

Justifica poucos resultados ou procedimentos, raramente explica os motivos.

Mantem ou defende, Independentemente das evidencias cu motivos, pontos de vista com base em interesse próprio ou preconceitos.

Significativamente Fraco 1: Executa de forma consistente todos ou quase todos os seguintes itens:

Fornece interpretaçð̄es tendenciosas de evidências, declaraç̋̃es, gráficos, perguntas, informaços, ou pontos de vista de outros.

Năo identifica ou rejeita precipitadamente contra-argumentos fortes e relevantes. Ignora ou avalia superficialmente os pontos de vista alternativos obvios.

Argumenta usando motivos equivocados ou irrelevantes, e motivos não justificados.

Năo justifica resultados ou procedimentos, nem explica os motivos.

Mantém ou defende os pontos de vista, Independente de evidéncias ou motivos, com base em interesses próprios ou preconceitos.

Demonstra mente fechada ou se recusa a pensar locicamente.

(c) 1094, 2000, 2011 Peter A. Facione, Norcen C. Facione, and Measuned Reasons LC, Homose Beach, CA USA

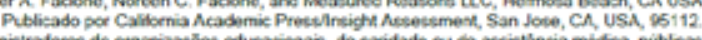

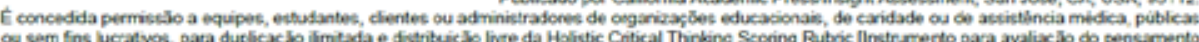

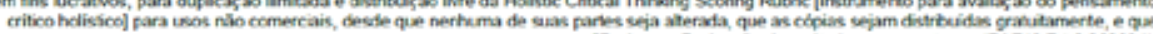
"Facione e Facione' sejan otados como autores. (PAF 49 R4 2062694 ) Para obter permiseho para incluir este instrumento em materiais que serio vendidos, entre em contato com a Insight Assessment. 1735 N 1 ST STREET, SUITE 306 
the application of PDE. In behavioral skills, for this group, there was a prevalence of self-confidence. And as for mind habits, confidence, curiosity, open mind, and intuition have prevailed.

After this step, the validation of the final version of the tool was consolidated. Figure 1 shows the HCTSR tool in the translated version for Brazilian Portuguese.

The HCTSR instrument is freely accessible and can be used free of charge while maintaining PhD author credits Peter A. Facione and can be used in all areas of knowledge. To learn how to use the instrument it is recommended to access the researcher's thesis or the Assessment Insight Platform, which will describe all the guidelines for using the instrument.

\section{DISCUSSION}

To assist the transformation of clinical practice into a humanized practice of care, the development of holistic critical thinking as an essential objective of education must be considered. When students are considered as human beings capable of thinking reflexive$l y$, the teacher is already recognizing the importance of considering the whole human being. Also, the curriculum will allow the students to do it when they begin their professional practice (FACIONE; CROSSETTI; RIEGEL, 2017). The HCTSR tool has a relevant contribution regarding the global assessment and development of critical thinking of nursing students who will be inserted in different contexts of clinical practice. They will require skills to think holistically in the nursing diagnosis process application (FACIONE, 2009).

This could be observed in a study in which HCTSR was applied to evaluate critical holistic thinking and clinical reasoning skills, with nursing undergraduate students through realistic simulations, with debriefing and guided reflexive diary to stimulate thinking. These practices showed effective measures to evaluate the level of reflection and critical thinking of academics (PADDEN et al., 2016). In this study, the importance of the assessment tool and its versatility in relation to the application are reaffirmed, since different teaching methodologies can be implemented to use HCTSR.

HCTSR represents an advance for the formative processes, with respect to the HCT evaluation in different academic and / or professional levels. The tool stresses new directions to the teaching and learning processes and leads to academic-professional education with new and effective configurations. The HCTSR can be used as a rich tool for probing previous know- ledge, also for the verification of advances obtained thought the process during the management of the knowledge acquired along an educational journey, for example. In this aspect, the validity of the tool is verified for initial, intermediate and conclusive moments of the various educational ways.

HCTSR was also applied in Thailand for the purpose of assessing students entering Thai universities enrolled in intensive English programs. The tool was appropriate to assess the evolution of critical thinking, allowing the comparison with the scores obtained at the beginning and at the end of the course. It helped teachers to identify improvements in teaching and learning processes (NANNI; WILKINSON, 2014).

However, for maximum use of tool's potential, it is pointed out the need of evaluators-teachers training / education in this critical and holistic perspective. They will have the capacity to mobilize the HCT skills on their own, providing more accurate assessment. In view of the nature of the tool, it reiterates its importance for conducting diagnostic assessments of academics regarding the holistic critical thinking level to guide them, from a theoretical model, with teaching strategies focused on those skills needed to be developed (FACIONE; FACIONE, 2009).

In the validation step of the HCTSR, it was possible to measure the HCT of nursing students, with the application of NDP to a clinical case. It has also successfully confirmed the applicability and results of HCTSR in HCT evaluation. HCT is a guide articulating and unifying all the relevant elements of a patient's clinical and human situation. To think holistically is to consider the well-being of the patient as an integrated whole, not seeing it as a momentary clinical issue or problem to be treated or solved isolated from the whole of the person's health and the circumstances of life (PADDEN et al., 2016).

The study, in this perspective, have collaborated to reaffirm the importance of the NDP to the practices of the nurse, to guide the nursing professional in the interpretation of the human responses to health and illness processes. Besides stimulating the search for evidences and its meaning by raising inferences about clinical decisions process. The nurse needs to think holistically to interpret evidence, considering the existence and singularity of a human being, emphasizing the human aspects. It involves caring, considering biopsychosocial and spiritual dimensions, historicity and temporality (FACIONE; CROSSETTI; RIEGEL, 2017).

It is possible for the teacher to be closer to the real way of thinking of different academics, facilitating the elaboration of NDP teaching activities focusing in- 
dividual needs. The tool becomes an ally for the construction of curriculum and practice considering the potential and weaknesses of each academic. These weaknesses can be worked through the whole educational process, with practices that makes the learner experience the theory and bring it to the center of the educational process, in a constant knowledge construction with the teacher and other students. As a weakness of the study, we identified the need to include in the evaluation with the use of HCTSR other teaching and evaluation methodologies, such as verbal presentations and written reports.

\section{CONCLUSIONS}

The translation, transcultural adaptation, and validation of the tool was guided by methodological rigor in all steps of the process. This aspect gives this study the appropriate academic relevance, since there has been the cultural conversion of a meaning. The results validated the tool translation and adaptation to Portuguese language - with emphasis on the variant used in Brazil - in consonance with the culture of its speakers. From this work, the HCTSR becomes, for the Brazilian reality - and in this case, especially for Nursing -, a tool of HCT measurement in tune with the culture of the Portuguese language speakers who can use it in their education. Future studies are recommended, with a focus on nurses training.

\section{REFERENCES}

ALEXANDRE, N. M. C.; COLUCI, M. Z. O. Content validity in the development and adaptation processes of measurement instruments. Ciência \& Saúde Coletiva, 16 (7), p. 3.061-3.068, 2011. Available from: http://www.scielo.br/ pdf/csc/v16n7/06.pdf.

BEATON, D. E.; BOMBARDIER, C.; GUILLEMIN, F.; FERRAZ, M. B. Guidelines for the process of cross-cultural adaptation of self-report measures. Spine, 25 (24), p. 3.186-3.191, 2007. Available from: http://citeseerx.ist.psu.edu/viewdoc/download;jsessionid=DD5AF47B40ED075FA02433D51D455102?doi=10.1.1.618.1464\&rep=rep1\&type=pdf.

BITTENCOURT, G. K. G. D.; CROSSETTI, M. G. O. Critical thinking skills in the nursing diagnosis process. Rev Esc. Enferm. USP, 47(2), p. 341-347, 2013. Available from: http:// www.scielo.br/pdf/reeusp/v47n2/10.pdf.
FACIONE, P. A. Critical Thinking: a Statement of Expert Consensus for Proposes of Educational Assessment and Instruction. California: Academic Press, 1 (1), p. 1-22, 1990. Available from: https://www.researchgate.net/ profile/Peter_Facione/publication/242279575_Critical_ Thinking_A_Statement_of_Expert_Consensus_for_Purposes_of_Educational_Assessment_and_Instruction/ links/5849b94508ae82313e7108de/Critical-Thinking-A-Statement-of-Expert-Consensus-for-Purposes-of-Educational-Assessment-and-Instruction.pdf.

FACIONE, P. A.; FACIONE, N. Holistic critical thinking scoring rubric. California: Academic Press, 2009. p. 1-2. Available from: https://www.insightassessment.com/Resources/Teaching-Training-and-Learning-Tools/Holistic-Critical-Thinking-Scoring-Rubric-HCTSR.

FACIONE, P. A. Critical Thinking and Clinical Reasoning in the Health Sciences. California: Academic Press, 2009. p. 1-5. Available from: https://www.insightassessment.com/Abou$\mathrm{t}$-Us/Measured-Reasons/pdf-file/aa-Clinical-Reasoning-Resource-PDFs/Using-the-Holistic-Critical-Thinking-Scoring-Rubric-to-Train-Discovery-of-Evidence-of-Critical-Thinking.

FACIONE, P. A.; GITTENS, C. A. Think Critically. California: Pearson Education, 2016.

FACIONE, P. A.; CROSSETTI, M. G. O.; RIEGEL, F. Holistic Critical Thinking in the Nursing Diagnostic Process [Editorial]. Revista Gaúcha de Enfermagem, 38(3), p. 755-776, 2017. DOI: http://dx.doi.org/10.1590/1983- 1447.2017.03.75576

LIMA, A. A. A.; CROSSETTI, M. G. O. Aplicação do modelo teórico de pensamento crítico no ensino do processo diagnóstico em enfermagem: uma experiência na prática clínica. Investigação Qualitativa em Saúde, 1(2), p. 552-561, 2016. Available from: https://proceedings.ciaiq.org/index. php/ciaiq2016/article/view/794/780.

NANNI, A. C.; WILKINSON, P. J. Assessment of ELLs' Critical Thinking Using the Holistic Critical Thinking Scoring Rubric. Language Education in Asia, 5(2), p. 283-91, 2014. Available from: http://www.leia.org/LEiA/LEiA\%20VOLUMES/Download/LEiA_V5_I2_2014/LEiA_V5I2A09_Nanni_Wilkinson. pdf.

NÓBREGA, M. M. L.; GUTTIERREZ, M. G. R. Equivalência semântica da classificação de fenômenos de Enfermagem da CIPE - versão alfa. João Pessoa: Idéia, 2000.

PADDEN, D. M. L.; SCAFFIDI, R. M.; KERLEY, R. M.; FARSI$D E, A$. L. Simulation With Debriefing and Guided Reflective Journaling to Stimulate Critical Thinking in Prelicensure Baccalaureate Degree Nursing Students. Journal Nursing Education, 55(11), p. 645-50, 2016. DOI: 10.3928/0148483420161011-07.

PAUL, S. A. Assessment of critical thinking: a Delphi study. Nurse Educ. Today, 34(11), p. 1.357-1.360, 2014. DOI: 10.1016/j.nedt.2014.03.008. 